\title{
Changes in growth, internode distance and nutrient concentrations of the seagrass Halophila ovalis with exposure to sediment sulphide
}

\author{
K. L. Kilminster ${ }^{1, *}$ D. I. Walker ${ }^{1}$, P. A. Thompson ${ }^{2}$, J. A. Raven ${ }^{3}$ \\ ${ }^{1}$ School of Plant Biology, The University of Western Australia, 35 Stirling Hwy., Crawley, Western Australia 6009, Australia \\ ${ }^{2}$ CSIRO Marine Research, GPO Box 1538, Hobart, Tasmania 7001, Australia \\ ${ }^{3}$ Division of Plant Sciences, University of Dundee at SCRI, Scottish Crop Research Institute, Invergowrie, Dundee DD2 5DA, UK
}

\begin{abstract}
Sulphide concentrations in estuarine sediments are likely to increase with increased organic matter fluxes (eutrophication) and increased temperatures (global warming). The short-term effects of sulphide on the growth, nutrition and morphology of the seagrass Halophila ovalis (R.Br.) Hook. f. were investigated in situ. Sediments within a $H$. ovalis meadow were enriched with $\mathrm{Na}_{2} \mathrm{~S}$ equivalent to $0,1.1$ and $4.2 \mathrm{~g} \mathrm{~m}^{-2}$. Sulphide diffusion tubes were estimated to increase sulphide concentrations by 1 to $4 \mathrm{mmol} \mathrm{l}^{-1}$, concentrations typical of elevated sulphide measured in natural systems. Biomass, internode distance and growth rate $\left(\mathrm{mg} \mathrm{apex}^{-1} \mathrm{day}^{-1}\right)$ were determined, and plant material was analysed for soluble carbohydrate, carbon, nitrogen and phosphorus. Sulphide exposure caused significant reduction in growth (63\%), average leaf weight (30\%) and internode distance $(15 \%)$. Above-ground tissue phosphorus concentration and internode distance were significant predictors of growth $\left(\mathrm{R}^{2}=0.63, \mathrm{p}<0.01\right)$. These results demonstrate the plasticity of $H$. ovalis in response to a short-term sulphide pulse, and may have implications for recovery from transient sulphide stress.
\end{abstract}

KEY WORDS: Sulphide $\cdot$ Sediments $\cdot$ Seagrass $\cdot$ Nutrients $\cdot$ Morphometrics $\cdot$ Growth constraint

\section{INTRODUCTION}

Seagrass roots and rhizomes may be both an asset and a burden (Hemminga 1998); they may be a burden since the growth and maintenance of roots and rhizomes have an associated energy cost and make plants vulnerable to unfavourable sediment conditions. Sediment biogeochemical processes may constrain seagrass growth, especially in the anoxic sediments prevalent in marine and estuarine systems (Hemminga 1998). In anoxic sediments, the reduction of sulphate to sulphide becomes the primary pathway for the decomposition of organic matter (Raven \& Scrimgeour 1997). Within-sediment biogeochemical processes, such as sulphate reduction, have received more recent research attention (Blaabjerg et al. 1998, Lee \& Dunton 2000, Azzoni et al. 2001) as factors in seagrass ecology. Although sulphide is a known phyto- toxin, the mechanism by which seagrasses tolerate this stress is not clearly understood. Sulphide is thought to be toxic to plants because it binds with the iron of cytochromes and other iron-containing compounds, inhibiting, among other enzymes, cytochrome oxidase, which is essential for the synthesis of ATP (Raven \& Scrimgeour 1997, Armstrong \& Armstrong 2005).

Exposure of below-ground roots and rhizomes of submerged macrophytes to 'free' sulphides depends on the many aspects of sediment biogeochemistry including (1) sulphate reduction rate (SRR), (2) porewater $\mathrm{pH}$, (3) potential of plant-produced oxygen to reoxidise sulphides and (4) availability of transition metals in sediment capable of sequestering sulphide. The role of seagrass in providing an organic substrate for heterotrophic sulphate-reducing bacteria is evidenced by generally higher SRRs in seagrass-vegetated sediments than in unvegetated sediments (Holmer et al. 
2003). Season also affects SRR, with typically higher rates in summer than in winter (Table 1). Concentrations of sulphide measured in porewater of seagrassvegetated habitats ranged from $<100 \mu \mathrm{mol} \mathrm{l}^{-1}$ to around $7 \mathrm{mmol} \mathrm{l}^{-1}$ free sulphides (Carlson et al. 1994, Terrados et al. 1999).

$\mathrm{H}_{2} \mathrm{~S}$ is thought to be the chemical species of reduced sulphur capable of permeating plant tissues (Raven \& Scrimgeour 1997). The alkalinity of sediment increases with sulphate reduction due to the production of hydroxyl ions, and the equilibrium of dissolved hydrogen sulphide $\left(\mathrm{H}_{2} \mathrm{~S} \times \mathrm{HS}^{-}+\mathrm{H}^{+} \times \mathrm{S}^{2-}+2 \mathrm{H}^{+}\right)$is $\mathrm{pH}$ dependent. At pH 8, which is typical of seawater, the equilibrium favours the formation of $\mathrm{HS}^{-}$species, with only $\sim 10 \%$ present as $\mathrm{H}_{2} \mathrm{~S}$. With a relatively small reduction in $\mathrm{pH}$, the equilibrium favours the formation of $\mathrm{H}_{2} \mathrm{~S}$, with $\sim 50 \%$ as $\mathrm{H}_{2} \mathrm{~S}$ at $\mathrm{pH}$ 7. Porewater within dense Thalassia testudinum Banks ex König meadows was $\sim 0.5 \mathrm{pH}$ units lower than in porewater of unvegetated sediment over the depth range of 8 to $20 \mathrm{~cm}$, measured at $4 \mathrm{~cm}$ intervals (Burdige \& Zimmerman 2002). If a pH drop of 0.5 is typical in seagrass rhizospheres, then it would raise the proportion of reduced sulphide present as $\mathrm{H}_{2} \mathrm{~S}$ in seagrass sediments by 2.5 -fold.

Hydrogen sulphide enters plants through the belowground plant parts primarily at night (Pedersen et al. 2004) when radial oxygen loss (ROL) from roots, a photosynthetically dependent process, is at a minimum (Connell et al. 1999, Jensen et al. 2005). Seagrass can re-oxidise sulphide that has entered the plant, leading to an accumulation of elemental sulphur $\left(\mathrm{S}^{0}\right)$ (Holmer et al. 2005). Sulphide re-oxidation presumably occurs in the aerenchyma, since the process is believed to be a chemical re-oxidation by $\mathrm{O}_{2}$ rather than mediated by plant or bacterial enzymes (Holmer et al. 2005).

The availability of free reduced sulphides in sediment porewater is also a function of the availability and redox state of sulphide-precipitable cations (such as $\mathrm{Fe}, \mathrm{Mn}, \mathrm{Cu}$ and other transition metals) within the sediment (Billon et al. 2001). Pools of precipitated sulphides in sediment have also been measured, usually

Table 1. Sulphate reduction rates (SRR) reported in the literature for seagrassvegetated sediments

\begin{tabular}{|llll|}
\hline Location (season) & Species & $\begin{array}{c}\text { SRR } \\
\left(\mathrm{mmol} \mathrm{m}^{-2} \mathrm{~d}^{-1}\right)\end{array}$ & Source \\
\hline France (summer) & Zostera noltii & $\sim 30$ & Welsh et al. (1996) \\
France (winter) & Zostera noltii & $\sim 5$ & Welsh et al. (1996) \\
Denmark (spring) & Zostera marina & $15-40$ & Holmer \& Laursen (2002) \\
Denmark (autumn) & Zostera marina & $10-20$ & Holmer \& Laursen (2002) \\
Spain (winter) & Posidonia oceanica & $1-4$ & Holmer et al. (2003) \\
Spain (summer) & Posidonia oceanica & $6-12$ & Holmer et al. (2003) \\
Thailand (winter) & Cymodocea rotundata & 6.6 & Holmer et al. (2001) \\
Thailand (winter) & Thalassia testudinum & 2 & Holmer et al. (2001) \\
\hline
\end{tabular}

as chromium-reducible sulphides (CRS) or total reducible sulphides (TRS), and these demonstrate the capacity and history of the sediment to alleviate sulphide inhibition of plant growth by precipitation with transition metal cations. Vastly different TRS (1 to $2 \mu \mathrm{mol} \mathrm{S} \mathrm{cm}{ }^{-3}$ and 50 to $140 \mu \mathrm{mol} \mathrm{S} \mathrm{cm}{ }^{-3}$ ) were measured in Zostera marina L. sediments with contrasting organic matter in Denmark (Holmer \& Laursen 2002), suggesting that either there is a higher availability of transition metal cations or more sulphides have been produced in the higher organic matter environment. Additionally, decreased seawater $\mathrm{pH}$ (ocean acidification) is expected to have a direct effect on shallowwater sediment chemistry, most notably influencing metal speciation with a higher proportion of metals present in the more toxic dissolved forms (Royal Society 2005). Ocean acidification may also have consequences for plant survivability in anoxic sediments, since lower $\mathrm{pH}$ favours $\mathrm{H}_{2} \mathrm{~S}$ (rather than $\mathrm{HS}^{-}$or $\mathrm{S}^{2-}$ ), the form of reduced sulphur capable of permeating membranes.

Sulphide concentrations present in seagrass-vegetated sediment may increase due to a number of factors. Increased temperature and increased organic matter deposition would increase bacterial activity, and reduction in photosynthesis by seagrass (i.e. reduced light) would reduce the rates of re-oxidation due to oxygen diffusing from root tips (Connell et al. 1999, Colmer 2003). Global warming and eutrophication are therefore processes likely to influence sulphide concentrations in seagrass-vegetated sediment and may reduce the survival of seagrass species that are sensitive to $\mathrm{H}_{2} \mathrm{~S}$.

Previous studies on the response of seagrass to sulphide as a stressor have appeared inconsistent. Seagrass response to reduced sulphides exposure has been tested directly (by adding $\mathrm{Na}_{2} \mathrm{~S}$ ) and indirectly (by adding sucrose to increase SRR), both in the field and the laboratory. Some species may tolerate sulphide exposure more effectively than others. For example, Thalassia testudinum tolerated 2 to $10 \mathrm{mmol}$ $\mathrm{l}^{-1}$ of sulphide with no clear reduction in leaf elongation or oxygen production rates (Koch \& Erskine 2001), whereas Halophila engelmannii Aschers. showed necrosis of tissue and eventual mortality at only $0.2 \mathrm{mmol} \mathrm{l}^{-1}$ reduced sulphide (Pulich 1983; see Table 3).

Halophila ovalis (R.Br.) Hook. f. is a small, fast-growing seagrass found in estuarine and marine habitats. This study focused on a meadow in shallow water $(<1 \mathrm{~m}$ deep), in the Swan River Estuary, Western Australia, at Pelican Point ( $\left.31^{\circ} 59^{\prime} \mathrm{S}, 115^{\circ} 49^{\prime} \mathrm{E}\right)$. The aim of 
this experiment was to examine in situ the short-term ( $<3 \mathrm{wk}$ ) effects of sulphide enrichment on growth and nutrient status of $H$. ovalis, explicitly testing the hypothesis that sediment sulphide enrichment would have a negative effect on the growth of $H$. ovalis. The study was completed during November and December 2005.

\section{MATERIALS AND METHODS}

Field experimental design. Plots $(\mathrm{n}=24)$ were randomly assigned in a $5 \times 5 \mathrm{~m}$ grid, at a spacing of $1 \mathrm{~m}$, within a Halophila ovalis meadow in shallow water ( $<0.5 \mathrm{~m}$ deep at low tide) in the Swan River Estuary, Western Australia. Plastic pots (165 mm diameter) defined each plot, and, to ensure sideways movement of porewater through these pots, the base was removed and 22 holes ( $2 \mathrm{~cm}$ diameter) were drilled in the sides. Treatments were assigned randomly to the plots. Sediment at the study site was predominantly siliceous sands.

Treatment additions. High sulphide, low sulphide and control (no sulphide) treatments were applied to the plots by insertion of diffusion tubes. Diffusion tubes were made of $6 \mathrm{~mm}$ diameter clear plastic tubing that was sealed at both ends with reticulation plugs. Each diffusion tube held $0.75 \mathrm{ml}$ of either deionised (DI) water or sodium sulphide solution, and had $1 \mathrm{~mm}$ holes drilled to release the treatment solution via diffusion at a depth of 5 to $8 \mathrm{~cm}$ into the sediment. PVC tape, temporarily sealing the holes, was removed concurrently with the insertion of diffusion tubes into the sediment. Treatments were control (3 diffusion tubes containing distilled water), low sulphide (3 diffusion tubes delivering a total of $0.023 \mathrm{~g}$ of $\mathrm{Na}_{2} \mathrm{~S}$ per plot, dissolved in distilled water) and high sulphide (3 diffusion tubes delivering a total of $0.09 \mathrm{~g}$ of $\mathrm{Na}_{2} \mathrm{~S}$ per plot, dissolved in distilled water). This corresponds to $0,1.1$ and $4.2 \mathrm{~g}$ $\mathrm{Na}_{2} \mathrm{~S} \mathrm{~m}^{-2}$, respectively. Sulphide treatments were estimated to enrich sediment porewater by 1 to $4 \mathrm{mmol} \mathrm{l}^{-1}$ (based on $20 \%$ porosity of sediment and the assumption of a diffusion zone of $5 \mathrm{~cm}$ depth within the pot). Although these solutions of sodium sulphide were basic ( $\mathrm{pH} 13$ to 14), the treatments were not expected to produce a substantial rise in porewater $\mathrm{pH}$, given that mixing of porewater over a $5 \mathrm{~cm}$ diffusion sphere would only produce a rise in $\mathrm{pH}$ on the order of $0.4 \mathrm{pH}$ units without the additional effect of $\mathrm{pH}$ buffering of the sediment porewater.

Sampling and analysis. Pots were left in the field for approximately $3 \mathrm{wk}$ and monitored by photo-quadrats prior to harvest. Approximately 100 underwater photographs of the plots were taken approximately every $4 \mathrm{~d}$ using an Olympus digital camera in underwater housing. The clearest of these for each of the plots was then colour- and contrast-adjusted in Corel Photo-paint 11 to enhance the image for counting the leaves. Estimates of leaf growth were made by counting leaves in $\sim 150$ digitally enhanced photographs as a relative percentage increase from the initial number of leaves present on Day 0.

Porewater was extracted in situ with porewater sippers at an integrated depth of 5 to $8 \mathrm{~cm}$ and analysed for sulphide (TPS ion selective electrode, Ag pellet) at the end of the experiment prior to harvesting of plant biomass. Whole plants (root, rhizome and leaves) were harvested with plant material placed on dry ice (to halt respiration) at the site, and then stored at $-20^{\circ} \mathrm{C}$ until analysis. For analysis, plant material was dissected into above- and below-ground biomass. Internode distance (distance between the second and third leaf pairs) and leaf and apex number per pot were determined. Since initial biomass within each plot could not be determined prior to experimental manipulation, leaf number counted from photographs at the outset of the experiment was used to estimate growth rate. Leaf growth, as mg apex ${ }^{-1} \mathrm{~d}^{-1}$, was calculated as the difference between initial and final leaf number multiplied by average leaf mass, then divided by the number of apices present at the end of the experiment and the length of the experiment. Leaf growth rate was converted proportionally via relative biomass allocation of above- and below-ground parts to give total growth rate expressed as mg apex ${ }^{-1} \mathrm{~d}^{-1}$. Epiphytes were removed from leaves by wiping with a tissue and scraping with a razor blade when necessary. Plant material was then re-frozen and freeze dried. Samples were finely ground with a Retsch Eppendorf grinder, then analysed for \% C and \% $\mathrm{N}$ with a LECO CHN analyser using a sample size of $\sim 100 \mathrm{mg}$. Plant tissue was digested and analysed for phosphorus colorimetrically by a method modified from Solorzano \& Sharp (1980) by Fourqurean \& Zieman (1992). Soluble carbohydrates were extracted from $\sim 50 \mathrm{mg}$ of finely ground tissue (above- and below-ground) for $20 \mathrm{~min}$ with $80 \%$ ethanol at $75^{\circ} \mathrm{C}$, and the concentration was determined by absorbance at $620 \mathrm{~nm}$ (Shimadzu 1240 UV-Vis spectrophotometer) using the anthrone colorimetric method (Yemm \& Willis 1954) with glucose standards.

\section{RESULTS}

Density of Halophila ovalis at the start of the experiment ranged from 470 to 1370 leaves $\mathrm{m}^{-2}$ with an average density of $810 \pm 250$ (SE) leaves $\mathrm{m}^{-2}$. Initial leaf density, although variable, was not significantly different across treatments $(p=0.692)$, and we made the assumption that the number of apices per leaf was also evenly distributed among treatments prior to sul- 
phide treatment. Leaf density increased during the $26 \mathrm{~d}$ experiment duration and ranged from 480 to 2420 leaves $\mathrm{m}^{-2}$. Although the site was very shallow, it is unlikely that light was saturating for seagrass during the whole experimental period. There was substantial macroalgal drift in the water column (Gracilaria and Cladophora spp.), which reduced irradiance reaching the seagrass meadow; however, this was a constant effect across controls and treatments.

The addition of sulphide to the sediment of a Halophila ovalis meadow caused significant changes to the plant. With increased sulphide addition, growth rate decreased $(p=0.024)$, internode distance decreased ( $\mathrm{p}=0.018$ ) and average leaf weight decreased $(\mathrm{p}=$ 0.017 ) as determined by 1-way analysis of variance (ANOVA) with treatment as a fixed factor (1-tailed test). The average growth rate of $H$. ovalis was reduced by $63 \%$ for the highest sodium sulphide loading $(4.2 \mathrm{~g}$ $\mathrm{m}^{-2}$ ) relative to the control (Fig. 1A). Average production on an areal basis decreased from $29.8 \mathrm{~g} \mathrm{~m}^{-2} \mathrm{~d}^{-1}$ in control samples to 22.8 and $14.0 \mathrm{~g} \mathrm{~m}^{-2} \mathrm{~d}^{-1}$ for low and
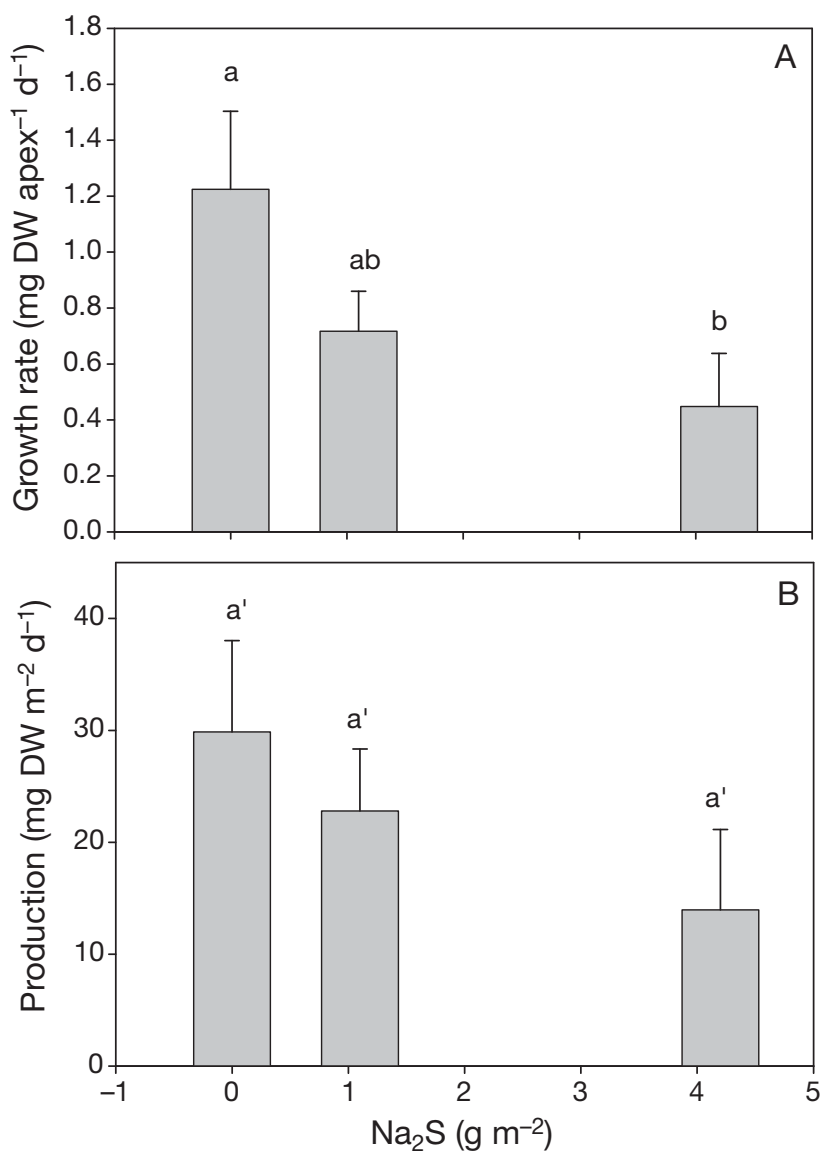

Fig. 1. Halophila ovalis. (A) Mean growth rate within pots (over a $26 \mathrm{~d}$ experiment duration) and (B) average dry weight production per $\mathrm{m}^{2}$ was reduced in $H$. ovalis exposed to $\mathrm{Na}_{2} \mathrm{~S}$. Columns represent mean $+1 \mathrm{SE}, \mathrm{n}=6-8$, and columns with shared letters are not significantly different $(p>0.05)$ high sulphide treatments (Fig. 1B). The negative effect of sulphide on the growth of $H$. ovalis was observed at the first sampling date by photo-quadrat leaf counts. The high sulphide treatment showed a reduction in leaf growth relative to the control and low sulphide treatment within the first week that was sustained until the end of the experiment (Fig. 2).

Above- and below-ground biomass was lower with sulphide exposure, although it was not significantly different from the control (Table 2). Average leaf mass and internode distance were reduced $\sim 30 \%$ and $\sim 15 \%$, respectively, for both sulphide treatments relative to the control (Fig. 3). Growth rate of Halophila ovalis was positively correlated with internode distance $\left(\mathrm{R}^{2}=0.414, \mathrm{p}<0.01\right.$; Fig. $\left.4 \mathrm{~A}\right)$.

There was no significant effect of sulphide treatment on the nutrient constituents $(\mathrm{C}, \mathrm{N}, \mathrm{P}, \mathrm{C}: \mathrm{N}: \mathrm{P}$ ratio and soluble carbohydrates) of Halophila ovalis (Table 2). Growth rate of $H$. ovalis was negatively correlated with both $\mathrm{N}$ :P ratio $\left(\mathrm{R}^{2}=0.350, \mathrm{p}<0.01\right)$ and concentration of phosphorus in above-ground plant parts $\left(\mathrm{R}^{2}=\right.$ 0.373, $\mathrm{p}<0.01$; Fig. 4B). Internode distance in $\mathrm{mm}$ (Internode) and concentration of phosphorus aboveground ( $\left.\% \mathrm{P}_{\text {above }}\right)$ as predictors of growth rate of $H$. ovalis accounted for $\sim 63 \%$ of the variability:

Growth rate =

$$
0.0498+(0.115 \times \text { Internode })-\left(3.93 \times \% \mathrm{P}_{\text {above }}\right)
$$

with $\mathrm{R}^{2}=0.632$ and $\mathrm{p}<0.01$ for all coefficients.

Sulphide enrichment of sediment appeared to be short-lived. The mean sulphide concentrations ( $\pm \mathrm{SE}$ ) in the porewater at the conclusion of the experiment were most variable in the control plots $\left(19 \pm 7 \mu \mathrm{mol} \mathrm{l}^{-1}\right)$ with lower mean concentrations measured in the plots treated with sodium sulphide $\left(7 \pm 2 \mu \mathrm{mol} \mathrm{l}^{-1}\right.$, low sulphide; and $13 \pm 3 \mu \mathrm{mol} \mathrm{l^{-1 }}$, high sulphide). Sulphide

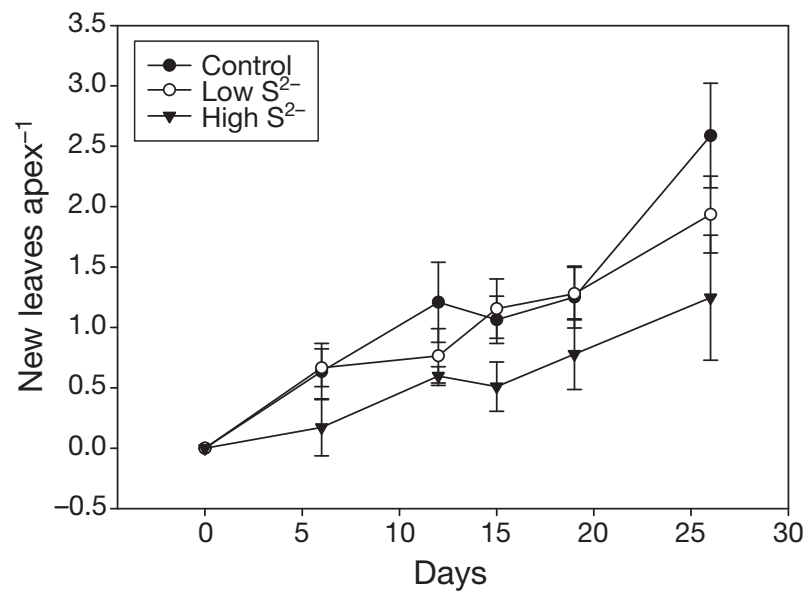

Fig. 2. Halophila ovalis. Production of new leaves per apex was reduced in the high sulphide treatment relative to the control within the first week (mean $\pm \mathrm{SE}, \mathrm{n}=6-8$ ) 
Table 2. Halophila ovalis. Plant biomass and nutrient allocation for above- and below-ground parts $\sim 3$ wk after sulphide enrichment showed no significant trend with treatment

\begin{tabular}{|c|c|c|c|c|c|c|c|c|c|c|}
\hline Treatment & $\mathrm{n}$ & $\begin{array}{c}\text { Biomass } \\
\left(\mathrm{g} \mathrm{m}^{-2} \pm \mathrm{SE}\right)\end{array}$ & $\begin{array}{c}\text { Biomass } \\
(\%)\end{array}$ & $\begin{array}{c}\% \mathrm{C} \\
(\% \pm \mathrm{SE})\end{array}$ & $\begin{array}{c}\% \mathrm{~N} \\
(\% \pm \mathrm{SE})\end{array}$ & $\begin{array}{c}\% \mathrm{P} \\
(\% \pm \mathrm{SE})\end{array}$ & $\begin{array}{l}\% \text { Carb. } \\
(\% \pm \mathrm{SE})\end{array}$ & $\mathrm{N}: \mathrm{P}$ & $C: N$ & $C: P$ \\
\hline \multicolumn{11}{|l|}{ Above-ground } \\
\hline Control $\left(0 \mathrm{~g} \mathrm{Na}_{2} \mathrm{~S} \mathrm{~m}^{-2}\right)$ & 6 & $780 \pm 140$ & 47.9 & $28 \pm 1.2$ & $1.5 \pm 0.07$ & $0.35 \pm 0.03$ & $1.8 \pm 0.4$ & 10.1 & 21.5 & 216 \\
\hline Low $\mathrm{S}^{2-}\left(1.1 \mathrm{~g} \mathrm{Na}_{2} \mathrm{~S} \mathrm{~m}^{-2}\right)$ & 8 & $600 \pm 100$ & 44.8 & $30 \pm 0.9$ & $1.7 \pm 0.09$ & $0.39 \pm 0.03$ & $1.5 \pm 0.2$ & 9.7 & 21.1 & 204 \\
\hline High $\mathrm{S}^{2-}\left(4.2 \mathrm{~g} \mathrm{Na}_{2} \mathrm{~S} \mathrm{~m}^{-2}\right)$ & 7 & $520 \pm 170$ & 46.4 & $29 \pm 0.7$ & $1.5 \pm 0.05$ & $0.34 \pm 0.04$ & $1.6 \pm 0.3$ & 10.9 & 22.2 & 244 \\
\hline \multicolumn{11}{|l|}{ Below-ground } \\
\hline Control $\left(0 \mathrm{~g} \mathrm{Na}_{2} \mathrm{~S} \mathrm{~m}^{-2}\right)$ & 6 & $850 \pm 120$ & 52.1 & $24 \pm 1.0$ & $0.86 \pm 0.03$ & $0.20 \pm 0.01$ & $7.9 \pm 1.1$ & 9.8 & 33.3 & 324 \\
\hline Low $\mathrm{S}^{2-}\left(1.1 \mathrm{~g} \mathrm{Na}_{2} \mathrm{~S} \mathrm{~m}^{-2}\right)$ & 8 & $740 \pm 120$ & 55.2 & $26 \pm 0.9$ & $0.94 \pm 0.03$ & $0.19 \pm 0.02$ & $6.8 \pm 1.2$ & 11.6 & 33.0 & 380 \\
\hline $\operatorname{High~}^{2-}\left(4.2 \mathrm{~g} \mathrm{Na}_{2} \mathrm{~S} \mathrm{~m}^{-2}\right)$ & 7 & $600 \pm 210$ & 53.6 & $27 \pm 1.4$ & $0.90 \pm 0.05$ & $0.19 \pm 0.01$ & $6.9 \pm 1.1$ & 10.4 & 35.4 & 367 \\
\hline
\end{tabular}

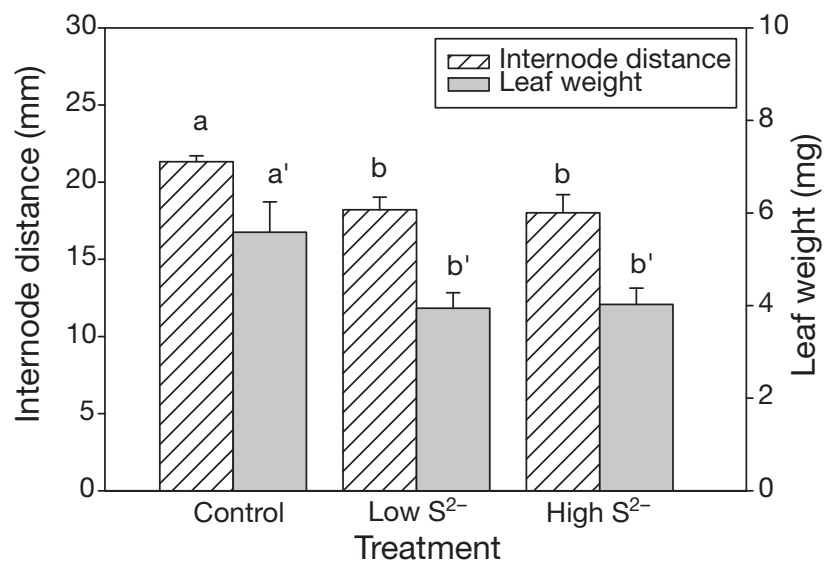

Fig. 3. Halophila ovalis. Average internode distance and average leaf weight were reduced with enrichment of sediment sulphide. Columns represent mean $+\mathrm{SE}, \mathrm{n}=6-8$, and columns with shared letters are not significantly different $(p>0.05)$

concentration on Day 26 was positively correlated to average leaf weight $\left(\mathrm{R}^{2}=0.683, \mathrm{p}<0.0005\right)$ and growth rate $\left(R^{2}=0.695, p<0.0005\right)$.

\section{DISCUSSION}

Seagrass tolerance to sulphide exposure has been tested directly (by adding $\mathrm{Na}_{2} \mathrm{~S}$ ) and indirectly (by adding sucrose to increase SRR), both in the field and the laboratory, but plant responses lack consistency (Table 3). The difficulty with indirectly increasing sulphides by increasing SRR is the interaction of plant anoxia, increased microbial competition for nutrients and sulphide stress. Additionally, elucidating field response of seagrass to sulphide exposure depends on the sediment type and the capacity of the sediment to sequester free sulphides.

Adding sulphide directly was an attempt to examine the effect of sulphide on the seagrass Halophila ovalis, without the parallel effects of enhanced anoxia or microbial competition for inorganic nutrients that
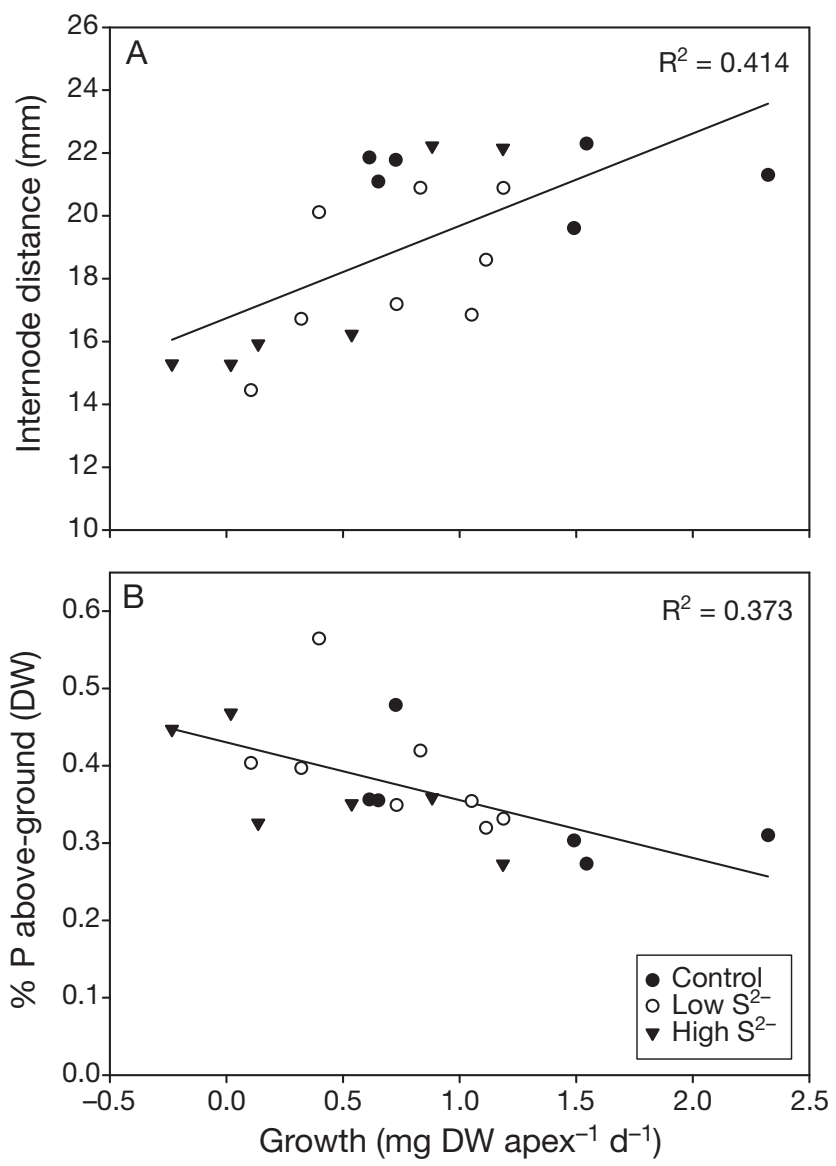

Fig. 4. Halophila ovalis. (A) Growth rate was positively correlated with internode distance and (B) negatively correlated with phosphorus concentration in above-ground plant parts for data from all treatments, $\mathrm{p}<0.01$

result from experiments in which sulphide accumulation is induced by adding sucrose or wrack (Kilminster et al. 2006). Our study would have benefited from measuring sediment sulphide during the experiment, as we do not have evidence of extended exposure of seagrass to sulphide and believe the enrichment to be shortlived. Our results support the hypothesis that short- 
Table 3. Seagrass tolerance to sulphide exposure, tested directly (by adding $\mathrm{Na}_{2} \mathrm{~S}$ ) and indirectly (by adding sucrose to increase sulphate reduction rates), both in the field and the laboratory. nd: not determined

\begin{tabular}{|c|c|c|c|c|}
\hline Species (Location) & Type & Enrichment & Response to treatment & Source \\
\hline $\begin{array}{l}\text { Cymodocea nodosa } \\
\text { (Spain) }\end{array}$ & Field & $\begin{array}{l}\text { Sucrose addition } \\
{\left[\mathrm{S}^{2-}\right] \approx 50 \mu \mathrm{mol} \mathrm{l}^{-1}}\end{array}$ & $\begin{array}{l}\text { No change in shoot density } \\
\text { or leaf growth rate }\end{array}$ & Terrados et al. (1999) \\
\hline $\begin{array}{l}\text { Cymodocea rotundata } \\
\text { (Philippines) }\end{array}$ & Field & $\begin{array}{l}\mathrm{Na}_{2} \mathrm{~S}\left(256 \mathrm{~g} \mathrm{~m}^{-2}\right) \\
{\left[\mathrm{S}^{2-}\right]=0.1-1 \mathrm{mmol} \mathrm{l}^{-1}}\end{array}$ & $\begin{array}{l}\text { Reduced growth rate of shoot, } \\
\text { root and rhizome; reduced } \\
\text { rhizome elongation }\end{array}$ & Halun et al. (2002) \\
\hline $\begin{array}{l}\text { Cymodocea rotundata } \\
\text { (Philippines) }\end{array}$ & Field & $\begin{array}{l}\mathrm{Na}_{2} \mathrm{~S}\left(512 \mathrm{~g} \mathrm{~m}^{-2}\right) \\
{\left[\mathrm{S}^{2-}\right]=0.08-0.12 \mathrm{mmol} \mathrm{l}^{-1}}\end{array}$ & $\begin{array}{l}\text { No change in growth rates; } \\
\text { reduced areal leaf and } \\
\text { sheath biomass }\end{array}$ & Halun et al. (2002) \\
\hline $\begin{array}{l}\text { Halophila engelmanni } \\
\text { (Texas, USA) }\end{array}$ & Lab & $\begin{array}{l}\text { Organic rich sediments } \\
{\left[\mathrm{S}^{2-}\right]=0.3 \mathrm{mmol} \mathrm{l}^{-1}}\end{array}$ & $\begin{array}{l}\text { Growth slowed; die-back with } \\
\text { leaf necrosis }\end{array}$ & Pulich (1983) \\
\hline $\begin{array}{l}\text { Halophila ovalis } \\
\text { (Western Australia) }\end{array}$ & Lab & $\begin{array}{l}\text { Sucrose addition } \\
{\left[\mathrm{S}^{2-}\right] \text { nd }}\end{array}$ & Reduced growth rate & Kilminster et al. (2006) \\
\hline $\begin{array}{l}\text { Halophila ovalis } \\
\text { (Western Australia) }\end{array}$ & Field & $\begin{array}{l}\mathrm{Na}_{2} \mathrm{~S}\left(1.1-4.2 \mathrm{~g} \mathrm{~m}^{-2}\right) \\
{\left[\mathrm{S}^{2-}\right] \text { nd during }} \\
\text { experiment }\end{array}$ & $\begin{array}{l}\text { Reduced growth rate, reduced } \\
\text { internode-distance, and reduced } \\
\text { average leaf mass }\end{array}$ & This study \\
\hline $\begin{array}{l}\text { Thalassia hemprichii (dom.) } \\
\text { (Philippines) }\end{array}$ & Field & $\begin{array}{l}\text { Sucrose addition } \\
{\left[\mathrm{S}^{2-}\right] \text { nd }}\end{array}$ & $\begin{array}{l}\text { No change in shoot density or } \\
\text { leaf growth rate }\end{array}$ & Terrados et al. (1999) \\
\hline $\begin{array}{l}\text { Thalassia hemprichii (dom.) } \\
\text { (Philippines) }\end{array}$ & Field & $\begin{array}{l}\text { Sucrose addition } \\
{\left[\mathrm{S}^{2-}\right] \approx 2 \mu \mathrm{mol} \mathrm{l}^{-1}}\end{array}$ & $\begin{array}{l}\text { Reduced shoot density and leaf } \\
\text { growth rate }\end{array}$ & Terrados et al. (1999) \\
\hline $\begin{array}{l}\text { Thalassia testudinum } \\
\text { (Florida, USA) }\end{array}$ & Lab & $\begin{array}{l}\mathrm{Na}_{2} \mathrm{~S} \\
{\left[\mathrm{~S}^{2-}\right] \approx 2-10 \mathrm{mmol} \mathrm{l}^{-1}}\end{array}$ & $\begin{array}{l}\text { No significant effect on leaf } \\
\text { elongation rate; no significant } \\
\text { effect on rhizome carbohydrates }\end{array}$ & Koch \& Erskine (2001) \\
\hline $\begin{array}{l}\text { Thalassia testudinum } \\
\text { (Florida, USA) }\end{array}$ & Lab & $\begin{array}{l}\mathrm{Na}_{2} \mathrm{~S} \\
{\left[\mathrm{~S}^{2-}\right] \approx 2-10 \mathrm{mmol} \mathrm{l}^{-1}}\end{array}$ & $\begin{array}{l}\text { Reduced leaf elongation rate; } \\
\text { reduced root ATP and energy } \\
\text { charge }\end{array}$ & Erskine \& Koch (2000) \\
\hline $\begin{array}{l}\text { Zostera marina } \\
\text { (Virginia, USA) }\end{array}$ & Lab & $\begin{array}{l}\mathrm{Na}_{2} \mathrm{~S} \\
{\left[\mathrm{~S}^{2-}\right]>800 \mu \mathrm{mol} \mathrm{l} l^{-1}}\end{array}$ & $\begin{array}{l}\text { Reduced photosynthetic rate; } \\
P_{\max } \text { decreased and } I_{\mathrm{C}} \text { increased }\end{array}$ & Goodman et al. (1995) \\
\hline $\begin{array}{l}\text { Zostera marina } \\
\text { (Denmark) }\end{array}$ & Lab & $\begin{array}{l}\text { Glucose addition } \\
{\left[\mathrm{S}^{2-}\right] \text { nd }}\end{array}$ & $\begin{array}{l}\text { Belowground } \mathrm{S}^{0} \text { accumulation; } \\
\text { growth rate decreased when } \\
\text { light also reduced }\end{array}$ & Holmer et al. (2005) \\
\hline $\begin{array}{l}\text { Zostera marina } \\
\text { (Denmark) }\end{array}$ & Field & $\begin{array}{l}\text { Sucrose addition } \\
{\left[\mathrm{S}^{2-}\right] \approx 70 \mu \mathrm{mol} \mathrm{l}^{-1}}\end{array}$ & $\begin{array}{l}\text { No change in shoot density; } \\
\text { reduced leaf growth rate }\end{array}$ & Terrados et al. (1999) \\
\hline
\end{tabular}

term sediment sulphide (or the indirect effects associated with it) negatively affects seagrass growth. Indirect effects may include changes in microbial nutrient demand and activity (due to sulphur-oxidising bacteria) and precipitation of essential trace metals. Nevertheless, in response to direct or indirect effects of adding sodium sulphide, $H$. ovalis had reduced growth rate and reduced areal production (Fig. 1), but showed morphological acclimation to sulphide exposure, producing leaves of smaller area and mass, and reduced internode distances (Fig. 3). Based on growth rate measurements, seagrass growth would halt altogether at enrichments of $6 \mathrm{~g} \mathrm{Na}_{2} \mathrm{~S} \mathrm{~m}^{-2}$ or greater, ultimately leading to death.

Reduced internode distance is likely to increase root and shoot density, since Halophila ovalis has a predominantly linear growth pattern with one root for every leaf pair. Branching rate was not measured explicitly in this study, although obvious differences in branching were not noticed during biomass processing. Since oxygen is lost diffusively through the roots of $H$. ovalis (Connell et al. 1999), reduced internode-distance and probable increase in root density may oxidise sediment sulphide, reducing total sulphide concentrations. Resulting sulphide concentrations will depend on the balance of oxygen and carbon provided to the sediment by the roots.

Additionally, this work demonstrates that measurements of biomass alone (above- or below-ground or ratio) were insufficient to reveal the negative response of seagrass to sulphide stress. Measurements of growth rate, production or an understanding of changes in plant morphology (reduced leaf weight) were necessary to demonstrate the negative impact of sulphide stress in this study. Biomass, a measurement commonly reported in seagrass studies, is not a very sensitive metric to environmental stress and as such should not be used to indicate a 'healthy' seagrass population 
without additional measurements of growth or production.

Other studies on seagrass tolerance to sediment sulphide (enriched either directly or indirectly) have produced contrasting responses (Table 3). In situ addition of sucrose has been used to increase SRR in seagrassvegetated sediment (Terrados et al. 1999, Nielsen et al. 2001), with a subsequent increase in porewater free sulphide concentration. Response of seagrass to sucrose enrichment appears to be variable across species and sites (Table 3), with reduction of growth rate, leaf elongation and shoot density the most common significant effects. To our knowledge, direct sulphide enrichment by the in situ addition of $\mathrm{Na}_{2} \mathrm{~S}$ has only previously been performed on Cymodocea rotundata. Reduced shoot and root production and reduced rhizome biomass and elongation were demonstrated for C. rotundata exposed to a significantly higher concentration of $\mathrm{Na}_{2} \mathrm{~S}\left(256 \mathrm{~g} \mathrm{~m}^{-2}\right)$ over a longer experimental duration (93 d; Halun et al. 2002). In our study, Halophila ovalis was negatively affected by a much lower sediment enrichment with $\mathrm{Na}_{2} \mathrm{~S}$ (maximum $4.2 \mathrm{~g}$ $\mathrm{m}^{-2}$ ). It is possible that the apparent difference in tolerance of the 2 seagrass species to sulphide enrichment is due to differences in ROL from roots. ROL has only been measured for 2 seagrass species, $H$. ovalis (maximum $135 \mathrm{nmol} \mathrm{O}_{2} \mathrm{~cm}^{-2} \mathrm{~h}^{-1} 0.5 \mathrm{~mm}$ behind root tip; Connell et al. 1999) and Zostera marina (maximum $78 \mathrm{nmol} \mathrm{O}_{2} \mathrm{~cm}^{-2} \mathrm{~h}^{-1} 1$ to $2 \mathrm{~mm}$ behind root tip; Jensen et al. 2005), although a number of wetland and nonwetland species have variable ROL (Colmer 2003). The apparent tolerance of $C$. rotundata to experimental addition of high sediment sulphide concentrations may be due to the increased sulphide concentration being offset by higher light levels (increasing photosynthetically linked ROL) and lower availability of sediment organic matter contributing to baseline sulphide concentrations (so SRR may be substrate limited) than $H$. ovalis experienced in this study.

Laboratory experiments of either direct or indirect sulphide enrichment avoid many of the confounding factors associated with site conditions, but are scarce in the literature. The photosynthetic rate of Zostera marina decreased in response to sediment sulphide (400 to $>800 \mu \mathrm{mol} \mathrm{l}^{-1}$; Goodman et al. 1995). Thalassia testudinum appeared tolerant to short-term $(<28 \mathrm{~d})$ below-ground sulphide exposure (Erskine \& Koch 2000) and showed mortality only when combined with additional stresses of light, salinity and temperature (Koch \& Erskine 2001).

Physiology helps define where seagrass can survive, so we can approach the question of seagrass tolerance to sediment sulphide indirectly by considering seagrass ecology. Halophila and Zostera are found in a large range of environments, from terrigenous muddy sediment typical of estuaries to organic-poor marine sediments. Since these seagrass genera are often found in muddy organic-rich sediments, we infer that these seagrasses may be better physiologically adapted to cope with the phytotoxin $\mathrm{H}_{2} \mathrm{~S}$ than genera such as Posidonia, which is only found in temperate, generally oligotrophic, environments. Physiological adaptation may manifest as differences in maximum root oxygen loss or shallower root systems, since shallower roots reduce exposure to sulphide, which increases with depth (Lee \& Dunton 2000). Different life strategies of the seagrass genera complicate issues, since Halophila and Zostera are fast-growing, opportunistic seagrasses and show rapid recovery from perturbation. Seagrasses at the other end of the generic seagrass model (Walker et al. 1999) such as Thalassia, Enhalus or Posidonia may appear to be tolerant of short-term sediment sulphide enrichment, but this may be a consequence of the slow response time of these seagrasses.

Sulphide enrichment did not significantly affect Halophila ovalis nutrient constituents. The concentrations of nutrients within leaves observed across all treatments showed slightly lower nitrogen concentrations and higher phosphorus concentrations than the median for seagrasses reported by Duarte (1990), but it is unlikely that growth of these seagrasses was nutrient limited. Sulphide addition did significantly reduce growth rate, and growth rate was negatively correlated with leaf phosphorus concentration and positively correlated with internode distance $\left(\mathrm{R}^{2}=0.63\right.$ for multiple linear regression). Higher leaf phosphate concentrations for plants with reduced growth rate may be due to either conservation (recycling from old to new growth), or increased phosphorus availability. Seasonal variation of tissue nutrient concentration is common for $H$. ovalis, with higher tissue nitrogen and phosphorus in winter than in summer (Hillman et al. 1995, Connell \& Walker 2001). The proposed linear regression model of growth, with leaf phosphorus and internode distance as predictors, requires further testing to allow for the effects of season, but it important to note that leaf phosphorus increases as a stress response.

Porewater sulphide concentrations, measured at the end of the experiment, did not show elevated concentrations in the treatment plots. Rather higher, and more variable, sulphide was measured in the control plots. These observations suggest that the initial elevated sulphide concentration imposed by the treatment had been eliminated over the $26 \mathrm{~d}$ experiment. While a number of fates are possible for the $\mathrm{H}_{2} \mathrm{~S}$, such as precipitation of metal sulphides or advection of porewater and exchange with the water column, the shortening of the internode distance and the loss of sulphide are 
consistent with the hypothesis that Halophila ovalis responds to oxidise sulphide in porewater.

Additionally, some sulphide production may be stimulated by seagrass growth (likely to be associated with photosynthetically released labile carbon in excess of ROL) since porewater sulphide concentrations were positively correlated with plant growth $\left(\mathrm{R}^{2}=0.695\right)$. The interaction of plant activity and microbial activity has been demonstrated for other seagrass species. Sulphate reduction rates in sediment vegetated by Zostera marina were positively correlated with the photosynthetic activity of the seagrass (Blaabjerg et al. 1998). Dissolved organic carbon (DOC) released by roots has been estimated at $1.6 \mathrm{~g} \mathrm{~m}^{-2} \mathrm{~d}^{-1}$ for the seagrass Cymodocea rotundata (Holmer et al. 2001). The labile DOC pool exuded by Thalassia testudinum was preferentially incorporated into bacterial biomass (Kaldy et al. 2006). A change in DOC and/or oxygen released by seagrass roots has the potential to shift the balance of oxygen and carbon in the rhizosphere, potentially affecting sediment sulphide concentrations.

Morphological acclimation by seagrasses is commonly observed; however, few studies can link these changes to a single process. Recent studies on other seagrass species have linked variation in morphology to environmental gradients (Irlandi et al. 2002, Miller et al. 2005, Peralta et al. 2005). Thalassia testudinum exposed to increased freshwater runoff (decreased salinity, increased turbidity and decreased light) showed reduced biomass, shoot weight, areal production and leaf width (Irlandi et al. 2002). Zostera noltii Hornemann produced small narrow leaves with long internodes in response to increased hydrodynamic flow following the creation of an artificial inlet (Peralta et al. 2005). A study of $Z$. tasmanica den Hartog across an environmental gradient of increased turbidity, increased water column chl $a$ and decreased light showed reduced leaf numbers per shoot, leaf weight per shoot, shoot length and internode distance, while overall seagrass cover and shoot density also decreased (Miller et al. 2005). Reduced light from increased turbidity is a common factor of these environmental impacts, and a reduction of oxygen and organic carbon fluxes from seagrass to the sediment may subsequently increase sediment sulphide concentrations. The most common effects of these environmental impacts are on leaf size and biomass production, effects also observed in this study.

Halophila ovalis has a global distribution, which is uncommon for many of the other highly specialised seagrass species. H. ovalis appears to be highly physiologically adaptable and tolerant of environmental extremes. It has been recorded at depths of $38 \mathrm{~m}$ (Huisman et al. 1999) and has been found in a sulphur-rich hot spring in Japan (Kuo et al. 2001). The plasticity demonstrated by $H$. ovalis in terms of adjusting internode distance in response to sulphide loading of sediment may provide a survival advantage. Elevated sulphide and elevated temperatures act synergistically with deleterious effects observed for 2 tropical seagrasses (Koch et al. 2007). Our study clearly demonstrates the adverse effects on $H$. ovalis of even shortterm sulphide elevation. Alteration of sediment chemistry, driven by climate change or eutrophication, that increases sediment sulphide may cause further declines in seagrass distribution in the coastal zones.

\section{LITERATURE CITED}

Armstrong J, Armstrong W (2005) Rice: sulfide-induced barriers to root radial oxygen loss, $\mathrm{Fe}^{2+}$ and water uptake, and lateral root emergence. Ann Bot (Lond) 96:625-638

- Azzoni R, Giordani G, Bartoli M, Welsh DT, Viaroli P (2001) Iron, sulphur and phosphorus cycling in the rhizosphere sediments of a eutrophic Ruppia cirrhosa meadow (Valle Smarlacca, Italy). J Sea Res 45:15-26

Billon G, Ouddane B, Laureyns J, Bourghriet A (2001) Chemistry of metal sulfides in anoxic sediments. Phys Chem Chem Phys 3:3586-3592

Blaabjerg V, Mouritsen KN, Finster K (1998) Diel cycles of sulphate reduction rates in sediments of a Zostera marina bed (Denmark). Aquat Microb Ecol 15:97-102

Burdige DJ, Zimmerman RC (2002) Impact of seagrass density on carbonate dissolutions in Bahamian sediments. Limnol Oceanogr 47:1751-1763

Carlson PRJ, Yarbro LA, Barber TR (1994) Relationship of sediment sulfide to mortality of Thalassia testudinum in Florida Bay. Bull Mar Sci 54:733-746

Colmer TD (2003) Long-distance transport of gases in plants: a perspective on internal aeration and radial oxygen loss from roots. Plant Cell Environ 26:17-36

Connell EL, Walker DI (2001) Nutrient cycling associated with the seagrass Halophila ovalis in the Swan-Canning Estuary based on seasonal variations in biomass and tissue nutrients. Hydrol Process 15:2401-2409

Connell EL, Colmer TD, Walker DI (1999) Radial oxygen loss from intact roots of Halophila ovalis as a function of distance behind the root tip and shoot illumination. Aquat Bot 63:219-228

$>$ Duarte CM (1990) Seagrass nutrient content. Mar Ecol Prog Ser 67:201-207

> Erskine JM, Koch MS (2000) Sulfide effects on Thalassia testudinum carbon balance and adenylate energy charge. Aquat Bot 67:275-285

Fourqurean JW, Zieman JC (1992) Phosphorus limitation of primary production in Florida Bay: evidence from C:N:P ratios of the dominant seagrass Thalassia testudinum. Limnol Oceanogr 37:162-171

> Goodman JL, Moore KA, Dennison WC (1995) Photosynthetic responses of eelgrass (Zostera marina L.) to light and sediment sulfide in a shallow barrier island lagoon. Aquat Bot 50:37-47

Halun Z, Terrados J, Borum J, Kamp-Nielsen L, Duarte CM, Fortes MD (2002) Experimental evaluation of the effects of siltation-derived changes in sediment conditions on the Philippine seagrass Cymodocea rotundata. J Exp Mar Biol Ecol 279:73-87

> Hemminga MA (1998) The root/rhizome system of seagrasses: an asset and a burden. J Sea Res 39:183-196 
Hillman K, McComb AJ, Walker DI (1995) The distribution, biomass and primary production of the seagrass Halophila ovalis in the Swan/Canning Estuary, Western Australia. Aquat Bot 51:1-54

Holmer M, Laursen L (2002) Effect of shading of Zostera marina (eelgrass) on sulfur cycling in sediments with contrasting organic matter and sulphide pools. J Exp Mar Biol Ecol 270:25-37

Holmer M, Andersen FØ, Nielsen SL, Boschker HTS (2001) The importance of mineralization based on sulfate reduction for nutrient regeneration in tropical seagrass sediments. Aquat Bot 71:1-17

Holmer M, Duarte CM, Marbà N (2003) Sulfur cycling and seagrass (Posidonia oceanica) status in carbonate sediments. Biogeochemistry 66:223-239

> Holmer M, Frederiksen MS, Møllegaard H (2005) Sulfur accumulation in eelgrass (Zostera marina) and effect of sulfur on eelgrass growth. Aquat Bot 81:367-379

Huisman JM, Sim CB, Walker DI (1999) A collection of deepwater marine plants from Rottnest Island. In: Walker DI, Wells FE (eds) The seagrass flora and fauna of Rottnest Island, Western Australia. Western Australian Museum, Perth, p 409-421

Irlandi E, Orlando B, Maciá S, Biber P and others (2002) The influence of freshwater runoff on biomass, morphometrics, and production of Thalassia testudinum. Aquat Bot 72 : $67-78$

Jensen SI, Kühl M, Glud RN, Jørgensen LB, Priemé A (2005) Oxic microzones and radial oxygen loss from roots of Zostera marina. Mar Ecol Prog Ser 293:49-58

Kaldy JE, Eldridge PM, Cifuentes LA, Jones WB (2006) Utilization of DOC from seagrass rhizomes by sediment bacteria: ${ }^{13} \mathrm{C}$ tracer experiments and modelling. Mar Ecol Prog Ser 317:41-55

Kilminster KL, Walker DI, Thompson PA, Raven JA (2006) Limited nutritional benefit of the seagrass Halophila ovalis, in culture, following sediment organic matter enrichment. Estuar Coast Shelf Sci 68:675-685

Koch MS, Erskine JM (2001) Sulfide as a phytotoxin to the tropical seagrass Thalassia testudinum: interactions with light, salinity and temperature. J Exp Mar Biol Ecol 266: 81-95

Koch MS, Schopmeyer SA, Kyhn-Hansen C, Madden CJ (2007) Synergistic effects of high temperature and sulfide on tropical seagrass. J Exp Mar Biol Ecol 341:91-101

Kuo J, Shibuno T, Kanamoto Z, Noro T (2001) Halophila ovalis (R. Br.) Hook. f. from a submarine hot spring in southern

Editorial responsibility: Kenneth Heck, Dauphin Island, Alabama, USA
Japan. Aquat Bot 70:329-335

Lee KS, Dunton KH (2000) Diurnal changes in pore water sulfide concentrations in the seagrass Thalassia testudinum beds: the effects of seagrasses on sulfide dynamics. J Exp Mar Biol Ecol 255:201-214

- Miller CJ, Campbell SJ, Scudds S (2005) Spatial variation of Zostera tasmanica morphology and structure across an environmental gradient. Mar Ecol Prog Ser 304:45-53

Nielsen LB, Finster K, Welsh DT, Donnelly A, Herbert RA, de Wit R, Lomstein BA (2001) Sulphate reduction and nitrogen fixation rates associated with roots, rhizomes and sediments from Zostera noltii and Spartina maritima meadows. Environ Microbiol 3:63-71

> Pedersen O, Binzer T, Borum J (2004) Sulphide intrusion in eelgrass (Zostera marina L.). Plant Cell Environ 27: 595-602

Peralta G, Brun FG, Hernández I, Vergara JJ, Pérez-Lloréns JL (2005) Morphometric variations as acclimation mechanisms in Zostera noltii beds. Estuar Coast Shelf Sci 64: 347-356

Pulich WMJ (1983) Growth response of Halophila engelmanni Aschers. to sulfide, copper and organic nitrogen in marine sediments. Plant Physiol 71:975-978

Raven JA, Scrimgeour CM (1997) The influence of anoxia on plants of saline habitats with special reference to the sulphur cycle. Ann Bot (Lond) 79 (Suppl A):79-86

Royal Society (2005) Ocean acidification due to increasing atmospheric carbon dioxide. The Royal Society, London

Solorzano L, Sharp JH (1980) Determination of total dissolved phosphorus and particulate phosphorus in natural waters. Limnol Oceanogr 25:754-758

- Terrados J, Duarte CM, Kamp-Nielsen L, Agawin NSR and others (1999) Are seagrass growth and survival constrained by the reducing conditions of the sediment? Aquat Bot 65:175-197

Walker DI, Dennison W, Edgar G (1999) Status of Australian seagrass research and knowledge. In: Butler A, Jernakoff P (eds) Seagrass in Australia: strategic review and development of an R \& D plan. CSIRO Publishing, Collingwood, p 1-24

> Welsh DT, Bourguès S, de Wit R, Herbert RA (1996) Seasonal variations in nitrogen-fixation (acetylene reduction) and sulphate-reduction rates in the rhizosphere of Zostera noltii: nitrogen fixation by sulphate-reducing bacteria. Mar Biol 125:619-628

Yemm EW, Willis AJ (1954) The estimation of carbohydrates of plant extracts by anthrone. Biochem J 57:508-514

Submitted: July 10, 2006; Accepted: March 13, 2008

Proofs received from author(s): May 26, 2008 